\title{
DOMINIUM QUOAD PROTECTIONEM: SAVEZ DVIGRADA S HUGONOM VIII. DEVINSKIM IZ 1386. GODINE
}

\author{
»Nam domini quibus in iurisdictione coactive obedire tenemur, \\ sunt qui per armatam potentiam defendere debent patriam«. \\ [Jer gospodari kojima smo dužni poslušnost u prinudnim nadležnostima, \\ oni su koji moraju oružanom silom braniti zemlju.] \\ Marsilije od Padove, Defensor pacis, pars 2, cap. 5.
}

Josip BANIĆ

Filozofski fakultet

Sveučilišta Jurja Dobrile u Puli

Pula, I. M. Ronjgova 1

jb@histria-historica.eu

\author{
UDK 930.85(450Aquileia)“14“" \\ UDK 94(497.571Dvigrad)“14““ \\ Izvorni znanstveni rad \\ https://doi.org/10.31726/via.28.4
}

Autor analizira dosad neobjavljenu ispravu iz 1386. godine kojom je sklopljen savez između dvigradske komune i Hugona VIII. Devinskog. Ističući razne poteškoće koje su krajem 14. stoljeća zadesile Akvilejski patrijarhat i Istarsku markgrofoviju, imenovanje Hugona VIII. advokatom Dvigrada tumači se u svjetlu jurisdikcijskoga pluraliteta i poroznih administrativnih granica istarskoga srednjovjekovlja. Autor zaključuje da je savez prvenstveno motiviran nemoću istarskih markgrofova da pruže odgovarajuću zaštitu građanima Dvigrada u tradicionalnim prekograničnim sukobima s podanicima susjedne Pazinske knežije i istovremenim jačanjem moći Hugona VIII. Rad završava transkripcijom isprave i njenim prijevodom na suvremeni hrvatski jezik.*

Ključne riječi: kasni srednji vijek, 14. stoljeće, Akvilejski patrijarhat, Istra, Dvigrad, Hugon VIII. Devinski, advokatura, Pazinska knežija

Keywords: Late Middle Ages, $14^{\text {th }}$ century, the Patriarchate of Aquileia, Dvigrad, Hugo VIII of Duino, guardianship, the County of Pazin

Parole chiave: tardo medioevo, XIV secolo, Patriarcato di Aquileia, Istria, Duecastelli, Ugo VIII di Duino, avvocatura, Contea di Pisino

Medievalni suverenitet nije bio monolitan, svaka je geopolitička tvorevina bila istodobno pod utjecajem nekoliko izvora vlasti. ${ }^{1}$ Osim univerzalno prisutne dihotomije između svjetovne i crkvene jurisdikcije, srednjovjekovne su zajednice nerijetko bile izložene utjecaju raznih političkih čimbenika koji su svoj suverenitet - u ovom radu definiran kao

\footnotetext{
Tekst je nastao radom na projektu $\gg$ ReCogniSeMe - Rituali, ceremonije i simboli hrvatskog srednjovjekovlja u europskom kontekstu (800. - 1600.)« Hrvatske zaklade za znanost (šifra: IP-2020-02), kojem je voditelj dr. sc. Robert Kurelić.

1 Ken PENNINGTON, »Sovereignty«, u: ISTI - David NAPOLITANO (ur.), A Cultural History of Democracy in the Medieval Age, A Cultural History of Democracy, sv. 2, Bloomsbury Academic, London, 2021., str. 17-36.
} 
pravo na izvršavanje sudske, zakonodavne ili političke ovlasti na određenom teritoriju ili društvenoj skupini - temeljili na raznolikim socijalnim, ekonomskim, vojnim i/ili simboličnim osnovama. ${ }^{2} \mathrm{U}$ doba prije formiranja snažnih centraliziranih teritorijalnih država s razvijenim birokracijama te monopolima na nasilje i ubiranje poreza, urbane i ruralne zajednice europskoga srednjeg vijeka plovile su u promjenjivu moru pluralnih suvereniteta, navigirajući u pravilu k pravcu koji im je istovremeno nudio najpovoljnije ekonomske uvjete, maksimalnu zaštitu i najopsežniju razinu lokalne autonomije. ${ }^{3}$ Samim je time suverenitet koncipiran recipročno, kao sustav prava i obveza, dužnosti na koje su međusobno obvezani kako podložnici, tako i njihovi vladari. ${ }^{4}$ Ukoliko bi suveren zakazao u izvršavanju svojih obligacija - prvenstveno u pružanju odgovarajuće obrane, promicanju interesa ili poštivanju uživanih privilegija svoje zajednice odnosno »dobrih starih zakona ili običaja« - riskirao bi gubitak legitimiteta i samim time redukciju svojih ovlasti. ${ }^{5}$ Nadalje, kao posljedica toga pluraliteta, jurisdikcijske su granice bile porozne i labilne, sklone mijenama u trenutcima nepoštivanja obveza koje nameće prakticiranje suvereniteta.

Istarski je poluotok u srednjem vijeku odličan primjer djelovanja pluralnih suvereniteta $\mathrm{i}$, posljedično, promjena administrativnih granica kao rezultata interakcija između mnogostrukih izvora autoriteta. Iako je de iure cijela regija formirana kao jedinstvena markgrofovija - Marchionatus Ystrie - i kao sastavni dio Svetoga Rimskog Carstva podređena 1209. godine akvilejskim patrijarsima, suverenitet careva i akvilejskih prelata od samoga je početka bio osporavan i nepotpun, izazivan kako od gradskih komunalnih autoriteta, tako i od moći regionalnoga svjetovnog plemstva, prvenstveno Goričkih grofova. ${ }^{6}$

2 Osim Penningtonova rada citiranoga u prethodnoj bilješci, o suverenitetu u srednjem vijeku vidi: Walter ULLMANN, »The Development of the Medieval Idea of Sovereignty«, The English Historical Review, sv. 44, br. 250 (1949.), str. 1-33; Stephen D. KRASNER, Sovereignty: Organized Hypocrisy, Princeton University Press, Princeton, 1999., str. 3-4; Robert JACKSON, Sovereignty: Evolution of an Idea, Polity Press, Cambridge, 2007., str. 1; Robert S. STURGES, »Introduction«, u: ISTI (ur.), Law and Sovereignity in the Middle Ages and the Renaissance, Arizona Studies in the Middle Ages and the Renaissance, sv. 28, Brepols, Turnhout, 2011., str. XI-XVIII; Francesco MAIOLO, Medieval Sovereignty: Marsilius of Padua and Bartolus of Saxoferrato (dalje: MAIOLO, Medieval Sovereignty), Eburon Academic, Delft, 2007., str. 28-29 i passim. Ponuđena se definicija suvereniteta temelji na Penningtonovu radu.

Za izgradnju država s naglaskom na srednjovjekovne preduvjete takvoga razvoja, Jørgen MØLLER, »Medieval Roots of the Modern State: The Conditional Effects of Geopolitical Pressure on Early Modern State Building«, Social Science History, sv. 42, br. 2 (2018.), str. 295-316.

5 Otto BRUNNER, Land and Lordship: Structures of Governance in Medieval Austria (dalje: BRUNNER, Land and Lordship), prev. Howard KAMINSKY - James VAN HORN MELTON, University of Pennsylvania Press, Philadelphia, 1992., str. 218-222; Susan REYNOLDS, Kingdoms and Communities in Western Europe, 900-1300, 2. izd., Oxford University Press, Oxford, 1997., str. XLVII-XLIX. Za praktične primjere ovoga koncepta vidi e.g. Massimo DELLA MISERICORDIA, »'Per non privarci de nostre raxone, li siamo stati desobidienti': Patto, giustizia e resistenza nella cultura politica delle comunità alpine nello stato di Milano (XV secolo)«, u: Cecilia NUBOLA - Andreas WÜRGLER (ur.), Forme della comunicazione politica in Europa nei secoli XV-XVIII: Suppliche, gravamina, lettere, Il mulino - Duncker \& Humblot, Bologna - Berlin, 2004., str. 147-215.

6 Vincenzo JOPPI (prir.), Aggiunte inedite al codice diplomatico istro-tergestino del secolo XIII, Tipografia di Giuseppe Seitz, Udine, 1878., dok. 1, str. 9-12. O genezi gospodstva Goričkih grofova u Istri temeljni je rad Peter ŠTIH, I conti di Gorizia e l'Istria nel Medioevo, Collana degli Atti, sv. 36, Centro di ricerche storiche, Rovigno - Unione Italiana, Fiume - Università popolare di Trieste, Rovinj, 2013. 
Vrhunac je ovoga jurisdikcijskog pluraliteta dosegnut sredinom 13. stoljeća, prelaskom akvilejskih patrijarha u filopapinski tabor i daljnjim dijeljenjem autoriteta na Poluotoku između mletačke, papinske (proakvilejske) i carske (progoričke) vlasti. ${ }^{7}$ Istarske su se zajednice raznoliko snalazile u ovom mnoštvu vlasti, međutim, u trenutku kada su nositelji suvereniteta zakazali u ispunjavanju svojih obaveza - prvenstveno prilikom neuspjeha da vojno obrane svoje podanike te uspostave stanje mira i sigurnosti - redovito bi dolazilo do gubitka legitimiteta i rušenja ovlasti. Na taj je način Akvilejski patrijarhat izgubio Poreč koji je prilikom napada Koprana (tada u savezu s Goričkima grofovima) obranu mogao osigurati jedino preko Venecije, ne mogavši se osloniti na pomoć svojih de iure suverenih, akvilejskih patrijarha. ${ }^{8}$ Ovaj je neuspjeh Akvilejskoga patrijarhata rezultirao cijelim nizom podčinjavanja istarskih priobalnih gradova Veneciji i, implicitno, urušavanjem suvereniteta glavara akvilejske Crkve na Istarskom poluotoku.

No potpuni prelazak pod vrhovnu vlast drugoga suverena samo je jedan model reagiranja na neprilike u međuodnosima vladara i podanika. Urušavanje autoriteta suverena - zbog neispunjavanja svojih obveza čuvanja mira, promicanja blagostanja i poštivanja običaja - moglo je rezultirati i drugim nuspojavama: širenjem autonomije podaničke zajednice (istovremeno preuzimajući na sebe i veće obveze) nauštrb prerogativa vladara ili sklapanjem saveza s drugim političkim čimbenicima u svrhu međusobne protekcije i promidžbe zajedničkih interesa. Na taj su način moćniji vlastodršci mogli iskoristiti slabost susjednih suverena, napadajući i pljačkajući njihove podanike, tražeći porez(e) na protekciju te tako šireći vlastiti autoritet nauštrb pada legitimiteta vladara nesposobnih za pružanje odgovarajuće obrane svojim podanicima. ${ }^{9}$ Upravo o ovakvom modalitetu pregovaranja suvereniteta i prenošenja jurisdikcijskih ovlasti u svjetlu traganja za boljom obranom i većom sigurnosti svjedoči isprava koja je u žarištu ovoga priloga, povelja sklapanja saveza između dvigradske komune i moćnoga plemića na vrhuncu svoje moći, Hugona VIII. Devinskoga.

Dana 26. svibnja 1386. okupili su se svi predstavnici komune u Dvigradu kako bi službeno i javno obznanili važnu novost za svoju zajednicu. Sudbonosnom su događaju prisustvovali dvigradski vikar, župnik, sudci i vijećnici komunalnoga vijeća, kao predstavnici komunalne uprave, te »cijela zajednica Dvigrada« koja je svojom prisutnošću dala legitimitet čitavom političkom ritualu. Te je subote dvigradska komuna formalno ponudila savez upravitelju susjedne Pazinske knežije, Hugonu VIII. Devinskom, i njegovu senioru,

7 Temeljni rad o ovoj problematici ostaje Giovanni DE VERGOTTINI, »La costituzione provinciale dell'Istria nel tardo Medio Evo«, Atti e memorie della Società istriana di archeologia e storia patria (dalje: $A M S I$ ), sv. 38, br. 2 (1926.), str. 81-127; isto, sv. 39, br. 1 (1927.), str. 9-60.

8 Roberto CESSI (prir.), Deliberazioni del Maggior Consiglio di Venezia, sv. 2, Atti della Assemblee costituzionali italiane dal Medio Evo al 1831, sv. 3/1: Parlamenti e Consigli Maggiori dei Comuni italiani, Bologna, 1931., dok. 46, str. 55; Katja PUPPE, Der lange Weg nach Istrien: Die venezianische Unterwerfung der Halbinsel, vornehmlich am Beispiel Kopers (1279-1349), doktorska disertacija, Leipzig, 2017., str. 33-48.

9 Riječima Wima Blockmansa, »In this way rulers who had a military superiority sold restraint in its use «: Wim BLOCKMANS, A History of Power in Europe: Peoples, Markets, States, Harry N. Abrams, Inc., Antwerp, 1997., str. 143. Vidi i: Aldo A. SETTIA, Rapine, assedi, battaglie: La guerra nel Medioevo, Laterza, Bari, 2002., str. 31-37; Andrea GAMBERINI, Clash of Legitimacies: The State-Building Process in Late Medieval Lombardy, prev. Stuart WILSON, Oxford University Press, Oxford, 2018., str. 171-172. 
Leopoldu Habsburškome, austrijskom vojvodi. Na taj je način ovom dvojcu dodijeljen položaj advokata Dvigrada, podrazumijevajući pod tom titulom vrhovne zaštitnike komune s dužnošću obrane kaštela i okolnoga distrikta. ${ }^{10}$ Zauzvrat su se žitelji Dvigrada obvezali na punu poslušnost svojim novim protektorima te na isplatu godišnjega danka na svetkovinu sv. Martina (11. studenoga) u iznosu od dvanaest maraka mletačkih solada. ${ }^{11}$ Dvigradski javni notar Ivan, sin pokojnoga Petra, sastavio je ovu službenu listinu kojoj je dodan viseći pečat komune - najstariji do danas sačuvani pečat Dvigrada - kako bi se utvrdio i dodatno osnažio legitimitet povelje. ${ }^{12}$

Ova je isprava gotovo nepoznata $u$ istarskoj historiografiji. Dokument je bio nepoznat Bernardu Schiavuzziju, autoru do danas najopsežnije i najutjecajnije studije o srednjovjekovnom Dvigradu, te se samim time ne spominje ni u suvremenijim prikazima dvigradske povijesti. ${ }^{13}$ Nadalje, povelju nisu poznavali ni velikani istarske medievistike, poput Bernarda Benussija, Giovannija De Vergottinija i Camilla De Franceschija, čije su publikacije i dalje glavna literatura za srednjovjekovnu povijest Istre. ${ }^{14}$ Jedini povjesničar koji je analizirao ovu ispravu, bio je Franc Kos u kontekstu svoje opsežne i hvalevrijedne studije

10 Hrvatski prijevod latinskoga termina advocatia i advocatus kao advokatura i advokat nije najbolje rješenje jer ti su hrvatski termini usko vezani uz semantičko polje pravne struke i sveučilišno obrazovanih pravnika, a to advokati o kojima je ovdje riječ, nikako nisu bili; usp. »Odvjetništvo«, u: Hrvatska enciklopedija, mrežno izdanje, Zagreb, 2021., dostupno na: http://www.enciklopedija.hr/Natuknica. aspx?ID=44785 (pristupljeno: 30 . listopada 2021.). U njemačkom se jeziku ovi termini prevode kao Vogtei i Vogt, u engleskom kao bailiff ili pak guard, guardianship - oba su prijevoda dovoljno različita od imenica poput Anwalt, advocate, lawyer koje pripadaju semantičkoj domeni pravne struke i sveučilišno obrazovanih pravnika. U hrvatskom jeziku, slično kao i u talijanskom, ovaj se termin uobičajeno prevodi kao advokat (tal. avvocato, avvocazia), ne čineći pritom razliku između svjetovnoga zaštitnika i sveučilišno obrazovanoga pravnika. Bez obzira na dosadašnju ustaljenu praksu, ovu bi distinkciju trebalo uvesti: jedno je potencijalno rješenje da se koristi termin zaštitnik kao prijevod latinskoga termina advocatus te termin zaštitništvo kao prijevod latinskoga termina advocatura kada ove dvije imenice ne podrazumijevaju sveučilišne pravnike i njihovu struku; drugi je, pak, da se uobičajeni termin advokat zadrži kao prijevod ovih latinskih termina koji nemaju veze s pravnom strukom, a da se sveučilišno obrazovane pravnike prevodi isključivo kao odvjetnike i njihove poslove kao odvjetništvo. U ovom sam radu izabrao potonji pristup. Zahvaljujem profesorici Nelli Lonzi koja mi je ukazala na ovaj terminološki problem u hrvatskom jeziku. Usp. Hans Joachim SCHMIDT, »Vogt, Vogtei«, u: Lexikon des Mittelalters, sv. 8, Artemis Verlag - LexMA-Verlag - Verlag-Metzler, Stuttgart, 1977. - 1999., kol. 1811-1814.

11 Riječ je o iznosu od 96 libara mletačkih denara. 1 solid $=12$ denara; 20 solada $=1$ libra; 1 marka $=8$ libara. Bernardo Maria DE RUBEIS, De nummis patriarcharum Aquileiensium dissertatio, sv. 2, Giambattista Pasquali, Venecija, 1749., str. 70.

12 Vidi dokument priređen $\mathrm{u} »$ Dodatku«.

13 Bernardo SCHIAVUZZI, »Due Castelli (Notizie storiche)« (dalje: SCHIAVUZZI, »Due Castelli...«), AMSI, sv. 31 (1919.), str. 81-118. Od novijih radova vidi: Maurizio LEVAK, »Nastanak i povijesni razvoj ranosrednjovjekovnog Dvigrada«, Annales, sv. 17, br. 2, (2007.), str. 305-314; Slaven BERTOŠA, »Dvigrad i njegovo područje: Povijesni pregled«, u: Nella LONZA - Jakov JELINČIĆ (prir.), Statuta communis Duorum castrorum / Statut dvigradske općine: Početak 15. stoljeća (dalje: LONZA - JELINČIĆ, Dvigradski statut), Kolana od statuti / Collana degli Statuti, sv. 1, Državni arhiv u Pazinu, Pazin, 2007., str. 19-31.

14 Bernardo BENUSSI, Nel Medio evo: Pagine di storia istriana, 2. izd., Collana degli Atti, sv. 23, Centro di ricerche storiche, Rovigno, Rovinj, 2004.; Giovanni DE VERGOTTINI, Lineamenti storici della costituzione politica dell'Istria durante il Medio Evo, 2. izd., Società istriana di archeologia e storia patria, Trst, 1974.; Camillo DE FRANCESCHI, »Ciò che resta e si sa di Due Castelli la città morta dell'Istria«, Archeografo triestino (dalje: AT), ser. 4, sv. 18-19 (1953. - 1954.), str. 321-335. 
o Devinskima. ${ }^{15}$ No Kos se u svom radu nije detaljnije bavio lokalnim prilikama u Dvigradu i Istarskoj markgrofoviji, već rastom moći Devinskih, stoga je analiza ovoga vrela ostala na razini utvrđivanja i nabrajanja titula i posjeda ove velikaške obitelji u trenutku njena zenita. Spremajući dosad najopsežniju i najkvalitetniju studiju o srednjovjekovnom Krasu, regiji u kojoj su Devinski predstavljali ključan politički čimbenik, ispravu je u kolekciji listina bečkoga Instituta za povijesna istraživanja (Institut für österreichische Geschichtsforshung) pronašao Miha Kosi koji je bio toliko ljubazan da ustupi svoju fotografiju dokumenta autoru ovoga priloga kako bi se ovo povijesno vrelo konačno objelodanilo i podvrglo temeljitijoj analizi. ${ }^{16}$

$* * *$

Suprotno neutemeljenim tvrdnjama starije historiografije, ne može se sa sigurnošću utvrditi kada je točno Dvigrad službeno prešao pod svjetovnu vlast akvilejskih patrijarha. ${ }^{17}$ Prvi i jedini izvor koji bi govorio o svjetovnoj vlasti akvilejske Crkve nad Dvigradom prije 1209. godine jest darovnica akvilejskoga patrijarha Ulrika Eppensteina dvigradskom gastaldu Vedellu iz 1096., dokument vrlo upitne autentičnosti. ${ }^{18}$ Iako ovo vrelo ne mora nužno svjedočiti o izravnoj vlasti Akvilejskoga patrijarhata nad Dvigradom, ono bi moglo govoriti u prilog tezi da su glavari akvilejske Crkve već prije 1209. godine imali utjecaja na području ovih dvaju kaštela. Iako su ispravom akvilejskoga patrijarha i istarskoga markgrofa Wolfgera iz 1211. godine, čija je autentičnost također upitna, porečkom biskupu Folkeru (lat. Fulcerius) potvrđena nedefinirana prava nad obama dvigradskim kaštelima, Monkaštelom i kaštelom Parentin, Dvigrad je ostao pod izravnom svjetovnom jurisdikcijom akvilejske Crkve i patrijarha-markgrofova. ${ }^{19}$ Porečkim je biskupima u Dvigradu ostalo pravo na ubiranje desetina i nekoliko kuća u izravnom vlasništvu, prava koja su redovito prepuštali svojim istaknutim osobama od povjerenja. ${ }^{20}$ Osim porečkih biskupa, određena nedefinirana prava u Dvigradu imali su i Gorički grofovi, koji su ih naslijedili od kuće Giroldi i potom investiturom prepustili obitelji Castropola. ${ }^{21}$

15 Franc KOS, »Iz zgodovine devinskih gospodov« (dalje: KOS, »Iz zgodovine...«), Razprave Znanstvenega društva za humanistične vede v Ljubljani, sv. 1 (1923.), str. 91-134.

16 Miha KOSI, Spopad na prehode proti Jadranu in nastanek »dežele Kras« (dalje: KOSI, Spopad), Založba ZRC, Ljubljana, 2018.

17 Schiavuzzijeva tvrdnja, da je Dvigrad 879. godine potpao in temporalibus Akvilejskom patrijarhatu, u potpunosti je netočna; usp. SCHIAVUZZI, »Due Castelli...«, str. 87.

18 Vincenzo JOPPI, »Documento inedito«, AT, ser. 2, sv. 13 (1887.), str. 459. Izdanje je loša transkripcija izvornika koji se nalazi u Udinama: Biblioteca civica "Vincenzo Joppi", Fondo principale, ms. 566/3: Memorialia Antonii Belloni notarii Utinensis, vol. 3, lib. 3, fol. 12v; rukopis iz prve polovice 16. stoljeća. Novo kritičko izdanje ovoga dokumenta osvanut će ubrzo na mrežnim stranicama projekta Fontes Istrie medievalis, https://fontesistrie.eu/.

19 Najbolje je izdanje ovoga dokumenta: Ante MATAN, »Excerpta manuscripti canfanariensis: Vladarske listine i papinska povlastica iz kodeksa Monumenta capituli Ecclesiae collegiatae S. Sophiae Duorum Castrorum ab anno 983.-1815«, Acta Histriae, sv. 21, br. 4 (2013.), str. 532-534.

20 Mirko ZJAČIĆ, »Posjedovni odnosi porečke crkve od VI. do XVI. stoljeća«, Jadranski zbornik, sv. 8 (1973.), str. 44, 86.

21 Pietro KANDLER (prir.), Codice diplomatico istriano (dalje: CDI), 2. izd., Tipografia Riva, Trst, 1986., sv. 3, dok. 516, str. 910-912; Camillo DE FRANCSESCHI, »Il comune polese e la signoria di Castropo- 
Dvigrad je svakako od 1209. pa sve do 1412. godine kao sastavni dio Markgrofovije Istre bio de iure svjetovni posjed Akvilejskoga patrijarhata. ${ }^{22}$ Iako je nekoliko puta mijenjao nadređene upravitelje - poput Henrika od Prate (dominus castri de Duobus Castellis de Ystria), ${ }^{23}$ izdanka obitelji Castropola (investicijom akvilejskih patrijarha 1328. godine), ${ }^{24}$ i Goričkih grofova (uzurpacijom u nekoliko navrata) ${ }^{25}$ - Dvigrad je tek krajem 1411. godine prestao biti podređen akvilejskim glavarima, prešavši najprije neformalno, a potom, tek 1413., formalno pod vlast Prejasne Mletačke Republike u jeku rata između Venecije i Žigmunda Luksemburškog, sukobom koji je rezultirao krahom svjetovnoga gospodstva akvilejske Crkve. ${ }^{26}$ Stoga je u vrijeme sklapanja saveza s Hugonom VIII. Dvigrad i dalje bio pod vrhovnom svjetovnom vlašću Akvilejskoga patrijarhata i to stanje potvrđuje kako mirovni ugovor u Torinu iz 1381., tako i dokumenti akvilejske kancelarije iz 1386. godine. ${ }^{27}$ No povelja o savezu iz 1386., sastavljena svega pet godina nakon potpisivanja

la«, $A M S I$, sv. 18, br. 3-4 (1902.) str. 306-307.

$22 C D I$, sv. 2, dok. 206, str. 380-383 (s time da se datum mora ispraviti na 1280. godinu; o toj novoj dataciji ovoga dokumenta trenutno pripremam rad koji bi trebao biti uskoro objelodanjen pod naslovom »Iura domini patriarche et Ecclesie Aquilegensis in tota Istria: A New Dating of an Undated Charter (CDI, 206)《).

23 Antonio Stefano MINOTTO, »Documenta ad Forumiulii Patriarchatum Aquileiensem, Istriam, Goritiam, Tergestum spectantia«, AMSI, sv. 11 (1896.), str. 244.

24 CDI, sv. 3, dok. 604, str. 1036-1037; isto, dok. 605, str. 1038; Camillo DE FRANCESCHI, »Il comune polese e la signoria di Castropola«, AMSI, sv. 19 (1903.), str. 161-162.

25 Vincenzo JOPPI, »Documenti goriziani del secolo XII e XIII«, $A T$, ser. 2, sv. 12, br. 1-2 (1886.), dok. 61, str. 80-83. Za povijesni kontekst vidi: Josip BANIĆ, »Buzet: Nepokolebljivi bastion kontinentalne Istre« (dalje: BANIĆ, »Buzet...«), u: Nella LONZA - Branka POROPAT (prir.), Buzetski statut / Statuto di Pinguente, Kolana od statuti / Collana degli Statuti, sv. 4, Grad Buzet / Città di Buzet, Buzet, 2017., str. 50-51.

26 Mletačka je vojska došla u pomoć Dvigradu u studenom 1411. kako bi se mjesto obranilo od očekivanoga napada kralja Žigmunda. Arthur STEINWENTER, »Studien zur Geschichte der Leopoldiner« (dalje: STEINWENTER, »Studien...«), Archiv für österreichische Geschichte, sv. 63 (1882.), str. 89-90. Dvigrad je najvjerojatnije od tada ostao pod mletačkom protekcijom. Primirjem između Venecije i kralja Žigmunda, potpisanim 17. travnja 1413. u Casteluttu kraj Rivignana, obje su strane dogovorile da se zadrži status quo i tada je Dvigrad, zajedno s Bujama, Ročom i Humom, i formalnopravno pripao Mletačkoj Republici. Tekst je mirovnoga sporazuma priređen u: Giambattista VERCI, Storia della Marca trivigiana e veronese (dalje: VERCI, Storia della Marca trivigiana), sv. 20, Venecija, 1786. - 1791., Giacomo Storti, sv. 19: appendix, dok. 2110, str. 64-66, i u: Šime LJUBIĆ (prir.), Listine o odnošajih izmedju južnog Slavenstva i Mletačke Republike, sv. 7, Monumenta spectantia historiam Slavorum meridionalium, sv. 12, JAZU, Zagreb, 1882., dok. 48, str. 104-105. O tom miru vidi Pier Silverio LEICHT, »L'esilio di Tristano di Savorgnano«, u: Studi di storia friulana, Società filologica friulana, Udine, 1955., str. 130-137. Nedugo potom, 1. veljače 1414. (1413. more Veneto), mletački dužd Toma (ven. Tomaso) Mocenigo službeno ozakonjuje formalan ulazak Dvigrada u Dominij Venecije, dodjeljuje komuni podestata koji će se svake godine birati u koparskom Velikom vijeću iz redova koparskoga plemstva i kojemu će dvigradska komuna isplaćivati godišnju plaću u visini od 390 libri mletačkih malih denara; $u s p$. LONZA - JELINČIĆ, Dvigradski statut..., str. 302. O ovom je sukobu između Venecije i kralja Žigmunda, s posebnim naglaskom na Istru, najdetaljnija studija: Josip BANIĆ, Venetian Istria in the Embrace of a Nascent Dominium (c. 1381 - c. 1470), doktorska disertacija, Budimpešta, 2021., str. 123-206.

27 Šime LJUBIĆ (prir.), Listine o odnošajih izmedju južnog Slavenstva i Mletačke Republike, sv. 4, Monumenta spectantia historiam Slavorum meridionalium, sv. 9, JAZU, Zagreb, 1868., dok. 241, str. 119-163; Arnold LUSCHIN VON EBENGREUTH, »I memoriali "Nobilis patriae forojulii,, dell'anno 1386 (LUCIFER AQUILEJENSIS)《 (dalje: LUSCHIN VON EBENGREUTH, »I memoriali...«), $A T$, ser. 2, sv. 16 (1890.), str. LXXVIII. 
Torinskoga mira, nigdje ne spominje ni Akvilejski patrijarhat ni istarskoga markgrofa, već samo neimenovanoga vikara. Kako je to moguće, tko stoji iza ureda vikara i zašto nigdje nema spomena dvigradskih legitimnih suverena?

Počevši od titule vikara, može se s određenom razinom sigurnosti zaključiti da se radi o uredu lokalnoga namjesnika istarskoga markgrofa. Isti je službenik također zvan i gastaldom, a komparativna analiza službe vikara, gastalda i kapetana u okviru srednjovjekovne Istarske markgrofovije pokazuje da se u suštini radi samo o različitim nazivima za istu službu: u Buzetu i Oprtlju markgrofov je namjesnik češće bio nazivan gastladom (iako se vikar spominjao i u Buzetu), dok se u Labinu istoga službenika nazivalo vikarom ili kapetanom. ${ }^{28} \mathrm{U}$ svakom se slučaju radilo o lokalnom namjesniku kojega je imenovao ili samo potvrđivao sam markgrof sa zadatkom ubiranja daća i administracije nižega sudstva, baš kao što je to bio slučaj i u Furlaniji. ${ }^{29}$ Više sudstvo, poglavito pravo prolijevanja krvi, bilo je u rukama delegiranoga markgrofa kojega bi na određeno vrijeme postavljao sam akvilejski patrijarh. Istarski markgrofovi osobno bi tijekom godine posjećivali svaki kaštel Markgrofovije, održavajući ceremonijalne sudske placite zajedno s lokalnim porotnicima. ${ }^{30} \mathrm{Samim}$ time autonomija je komuna Istarske markgrofovije bila ograničena autoritetom akvilejskih patrijarha $\mathrm{i}$ istarskih markgrofova, dok su gastaldi/vikari/kapetani služili samo kao spona između lokalne zajednice i patrijarhovih regionalnih namjesnika. Prema ovoj administrativnoj shemi, dvigradska komuna ne bi mogla samostalno sklopiti savez s Hugonom VIII. Devinskim i Leopoldom Habsburškim, tim više što je jedan od glavnih prerogativa i zadaća istarskih markgrofova bila upravo obrana podanika akvilejske Crkve. Ova upravna struktura, međutim, nije uvijek funkcionirala u praksi.

Moć je istarskih markgrofa prvenstveno ovisila o autoritetu akvilejskih patrijarha. Ukoliko je na Stolici sv. Hermagore sjedio snalažljiv političar koji je oko sebe uspio okupiti moćne plemiće kao vjerne podržavatelje i sklopiti korisne saveze sa susjednim silama, istarski je markgrof mogao računati na odgovarajuću vojnu pomoć te je samim time ulijevao veće poštovanje kako kod svojih podanika, tako i kod potencijalnih suparnika. ${ }^{31}$ No u trenutcima bi se krize i razdora u svjetovnom gospodstvu akvilejskih patrijarha, krvavih epizoda ratnih okršaja među sukobljenim taborima, kojih u četrnaestom stoljeću nije bilo malo, urušavala i moć istarskih markgrofova te, posljedično, utjecaj i ugled njihova ureda. Najpoznatiji je primjer takvoga pada autoriteta, koji je doveo do posvemašnje neposluš-

28 BANIĆ, »Buzet...«, str. 60-61; Camillo DE FRANCESCHI, »Statuta communis Albonae«, AT, ser. 3, sv. 7 (1908.), str. 134-137.

29 Pier Silverio LEICHT (prir.), Parlamento friulano (dalje: $P F$ ), sv. 1, br. 1, Atti della Assemblee costituzionali italiane dal Medio Evo al 1831, sv. 1/6: Stati generali e provinciali: Parlamento friulano e stati provinciali goriziani, Bologna, 1917., str. XXIV-XVIII; Dea MOSCARDA, »Sugli ordinamenti dei comuni rustici del Friuli pedemontano e patriarchino tra XIV e XV secolo«, Memorie storiche forogiuliesi, sv. 74 (1994.), str. 113, 166-167.

30 Vincenzo JOPPI, »Diritti di Aquileia nel Marchesato d'Istria (anno 1381)«, AT, ser. 2, sv. 9, br. 1-2 (1883.), str. 195-199; BANIĆ, »Buzet...«, str. 60-61.

31 Elisabeta SCARTON, »Il patriarcato di Aquileia: Una storia "sbagliata""«, u: Matteo VENIER - Gabriele ZANELLO (ur.), Cultura in Friuli III: Settimana della cultura friulana / Setemane de culture furlane, 5-16 maggio 2016, Società filologica friulana, Udine, 2017., str. 626-633. 
nosti akvilejskih podanika u Istri, pismo markgrofa Bernarda da Oltrepontea patrijarhu Antoniju Caetaniju iz 1398. godine. ${ }^{32}$ Tako su, naprimjer, na naredbu svoga markgrofa da vrate ukradene stvari grofici Ani Goričkoj, Buzećani u neposluhu odgovorili: »Kada naši mrtvi uskrsnu, rečeno ćemo vratiti!«, a sam Bernard žalio se patrijarhu da od svoje službe u Istri nije dobio »ni pet florena«, »ni ikoji dio kruha ni vina ${ }^{33}$ Pad legitimiteta markgrofa ležao je u nemogućnosti pružanja primjerene obrane od gotovo svakodnevnih pljačkaških upada na teritorij Buzeta: »Kakvu pomoć ti nama daješ? Jesu li to tvoji ljudi koje nama šalješ u pomoć? Kakav si ti to markgrof?« - ljutito su Buzećani napadali nemoćna Bernarda od Oltrapontea. ${ }^{34}$

Iz ovoga je gotovo komičnoga povijesnog vrela jasno vidljiva veza između vladarove mogućnosti pružanja odgovarajuće obrane svojim subjektima i poslušnosti podaničke zajednice: ukoliko zadatak obrane padne na lokalnu zajednicu, utoliko vladari gube temelj na kojem im počiva legitimitet, pa i suverenitet posljedično prelazi s gospodara na subjekte. Prepušteni sami sebi podanici preuzimaju višu razinu odgovornosti i posljedično šire vlastitu autonomiju nauštrb prerogativa oslabjela vladara. Slična situacija rapidnoga pada moći patrijarha dogodila se i 1380-ih godina, u doba velikoga političkog razdora u Akvilejskom patrijarhatu čije su se posljedice osjetile i u Istri.

Naime, nakon smrti patrijarha Markvarda od Randecka (†3. siječnja 1381.) papa Urban VI. imenovao je Filipa d'Alençona, kardinala i suburbikarnoga biskupa Sabinske biskupije, novim glavarom akvilejske Crkve in commendam. ${ }^{35}$ Ovo dodjeljivanje Akvilejskoga patrijarhata kao komende predstavljalo je »novotariju« koju velik dio furlanskoga stanovništva nije željelo prihvatiti. ${ }^{36}$ Ubrzo je uslijedio razdor u Furlaniji između podržavatelja novopostavljenoga patrijarha te frakcije koju su predvodile Udine i koja je ostala vjerna savezu s ugarskim kraljevstvom, želeći od Pape izboriti novo imenovanje "pravoga patrijarha«, po mogućnosti vjernoga dvoru kralja Ludovika Anžuvinskog. ${ }^{37}$ Cijeli je sukob poprimio nove dimenzije kada je i sam kralj Ludovik odustao od »akvilejske avanture« i svojim

32 Pismo je objavljeno in extenso u: $C D I$, sv. 3, dok. 863, str. 1473-1476 (s time da se datacija mora ispraviti na 1398. godinu, kao što to ispravno čini Pio PASCHINI, »L'Istria patriarcale durante il governo del patriarca Antonio Caetani (1395-1402)«, AMSI, sv. 42 (1930.), str. 113-115. Više o tom pismu u: BANIĆ, »Buzet...«, str. 65-66.

33 »Mihi responderunt quod quando mortui eorum resurgent, predicta restituent.« ... »per fidem meam nondum recepi quinque florenos de iuribus Marchionatus, nec aliquam partem panis et vini«; $C D I, \mathrm{sv} .3$, dok. 863 , str. $1475-1476$.

»Qui [illi de Pinguento] improperabant mihi dicentes: est hoc auxilium quod tu das nobis? Sunt iste gentes quas nobis in auxilium exhibes? Cuiusmodi Marchio es tu?«; CDI, sv. 3, dok. 863, str. 1476.

35 Bernardo Maria DE RUBEIS, Monumenta Ecclesiae Aquileiensis commentatio historico-chronologico-critico illustrata, Giambattista Pasquali, Venecija, 1748., kol. 960-961; Pio PASCHINI, Storia del Friuli (dalje: $S D F$ ), 3. izd., Arti Grafiche Friulane, Udine, 1975., str. 586; Josip BANIĆ, »Okupacija ili protektorat? Markgrofovija Istra pod Dujmom od Castella osamdesetih godina 14. stoljeća« (dalje: BANIĆ, »Okupacija...«), Zbornik Odsjeka za povijesne znanosti Zavoda za povijesne i društvene znanosti Hrvatske akademije znanosti i umjetnosti, sv. 37 (2019.), str. 8.

36 Temeljna je literatura o ovom sukobu: $S D F$, str. 586-629. Vidi također i: BANIĆ, »Okupacija...«, str. 8-13.

$37 P F$, sv. 1, br. 2, Bologna, 1927., str. 337-338. 
vjernim saveznicima preporučio poslušnost Filipu d'Alençonu i savez s gospodarom Padove, Franjom (tal. Francesco) da Carrarom. ${ }^{38}$ Unija Alençon - Carrara, sklopljena ubrzo, bila je plodna: patrijarh je gospodaru Padove prepustio utvrdu San Polo di Piave koju je Da Carrara uspješno iskoristio u osvajanju habsburškoga Trevisa. ${ }^{39}$ Udine, predvođene obitelji Savorgnan, i dalje nisu bile spremne prihvatiti Filipa d'Alençona kao svoga legitimnog vladara. Nakon osvajanja Trevisa nezadovoljna vlašću patrijarha d'Alençona bila je i susjedna Venecija koja se osjećala ugroženom savezom akvilejskoga patrijarha i gospodara Padove, tradicionalnih neprijatelja Prejasne kraljice Jadrana. Nedugo potom, 8. veljače 1385., u Gradežu je službeno sklopljena »Sretna unija« (orig. lat. Unio felix, Liga felici, Felix liga), savez predvođen Venecijom, Udinama i obitelji Savorgnan koji je bio uperen protiv utjecaja Da Carrare i, posljedično, patrijarha d'Alençona u Akvilejskom patrijarhatu. ${ }^{40}$

Članom ovoga saveza protiv legitimnoga akvilejskog patrijarha bio je i Dujam od Castella, markgrof Istre od 1379. godine, kojega je notar i patrijarhijski kancelar Ulrik od Susanne, pristalica d'Alençona, nazivao »okupatorom « Markgrofovije Istre. ${ }^{41}$ Cijeli sukob između zaraćenih furlanskih tabora, koji su uključivali Veneciju s jedne i Padovu s druge strane, okončan je tek nakon službene smjene patrijarha d'Alençona i imenovanja novoga glavara akvilejske Crkve, Ivana Soběslava Moravskog (1388. - 1394.) te potpisivanjem mirovnoga sporazuma između Čedada i Udina (21. veljače 1391.). ${ }^{42}$ Ubrzo je imenovan i novi, univerzalno priznat istarski markgrof - Hordibor. ${ }^{43}$

Godine 1386., kada je dvigradska komuna sklopila savez s Hugonom VIII. od Devina, Istarska je markgrofovija, kao i cijela državina akvilejskih patrijarha, bila u krajnje neizvjesnom stanju građanskoga rata. Samim time, legitimitet je istarskoga markgrofa Dujma od Castella, podržavatelja promletačke i antipatrijarhijske stranke, bio upitan. Iako povijesni izvori pokazuju da je Dujam izvršavao svoje markgrofovske dužnosti u skladu s »dobrim starim običajima«, ne postoji nijedan dokument koji bi svjedočio o njegovoj upravi u Dvigradu. ${ }^{44}$ Vrlo je moguće da je kao jedan od glavnih stupova »Sretne unije« bio suviše zaokupljen svojim dužnostima u Furlaniji te da je administracija Istarske markgrofovije, pavši u drugi plan, bila zanemarivana više negoli je to bio slučaj u prethodnim razdobljima.

38 Udine, Biblioteca civica „Vincenzo Joppi”, Fondo principale, ms. 899: Giuseppe BIANCHI (prir.), Documenti per la storia del Friuli, 1200-1400 (Diplomatarium Foroiuliense), dok. 4892.

VERCI, Storia della Marca trivigiana..., sv. 16, Venecija, 1790., appendix: dok. 1789; SDF, str. 595.

Izvorna listina u Archivio di Stato di Venezia (dalje: ASV), Miscellanea atti diplomatici e privati, b. 25, br. 766.

41 LUSCHIN VON EBENGREUTH, »I memoriali...«, str. LXXVIII; BANIĆ, »Okupacija...«, str. 3, 15-18.

42 Ondřej SCHMIDT, John of Moravia between the Czech Lands and the Patriarchate of Aquileia (ca. 1345-1394), prev. Graeme DIBBLE - Suzanne DIBBLE, East Central and Eastern Europe in the Middle Ages, 450-1450, sv. 56, Brill, Leiden - Boston, 2019., str. 139; BANIĆ, »Okupacija...«, str. 13.

43 [Tomaso LUCIANI (prir.)], »Senato misti - cose dell'Istria«, AMSI, sv. 5, br. 3-4 (1889.), str. 288-289. O ovom misterioznom liku, očito čovjeku od povjerenja i zemljaku akvilejskoga patrijarha Ivana, ne zna se apsolutno ništa.

44 BANIĆ, »Okupacija...«, str. 18-24 i dokumenti objavljeni na str. 30-33. 
S druge strane, Hugon VIII. od Devina istodobno je stajao na samom zenitu svoje moći, kao jedan od najmoćnijih velikaša sjevernoga Jadrana. ${ }^{45}$ Godine 1366 . ovaj se izdanak Kuće Devin službeno podložio obitelji Habsburg, zamijenivši svoje stare seniore, akvilejske patrijarhe i onemoćale Goričke grofove moćnim vojvodama Austrije. ${ }^{46}$ Ova je smjela politička odluka uzdigla izvorno ministerijalsku obitelj Devinskih na nove razine moći i ugleda: postavši austrijskom zemaljskom gospodom (Lanndheren), dobili su privilegij kojim su bili podložni isključivo austrijskom plemićkom sudu (Lanndschranne). ${ }^{47}$ Štoviše, 1374. godine Hugon VIII. posvjedočen je i kao markgrof akvilejske Markgrofovije Istre kojemu je patrijarh Markvard prepustio selo Boljun (orig. Dorff Vaniol gelegen ze Isterreich).$^{48}$ Najvažnije se imenovanje dogodilo krajem 1379. godine, nakon što su smrću grofa Alberta III. (1374.) svi istarski posjedi Goričkih grofova nasljednim ugovorom prešli u ruke austrijskih vojvoda: Hugon VIII. tada je imenovan kapetanom habsburške Istarske grofovije (koja je uključivala i Pazinsku knežiju). ${ }^{49}$ Nakraju, godine 1386 . Hugon VIII. posvjedočen je kao glavar još dvaju habsburških posjeda - kao kapetan Trsta i Kranjske marke. ${ }^{50}$ Dok je moć akvilejske Crkve i istarskih markgrofova bila u krizi zbog rata u Furlaniji, Hugon VIII. Devinski profilirao se kao najmoćniji uglednik u cijeloj sjevernojadranskoj regiji.

U jeku rata između udinske (promletačke) i čedadske (propadovanske) frakcije u Furlaniji, Devinski su formalno ostali neutralni. Neformalno, međutim, Hugon VIII. podržavao je Da Carraru i akvilejskoga patrijarha d'Alençona. Tako je Da Carrarina vojska u siječnju 1384. pronašla utočište u Raklju, posjedu pod upravom Hugona VIII. kao kapetana Istarske grofovije, i upravo su iz Raklja ove protumletačke sile izvršile pljačkaški upad u susjednu venecijansku Pulu. ${ }^{51}$ Štoviše, Devinski su sljedeće godine napali i promletački Monfalcone..$^{52}$ Stoga se zaključuje da je promletački istarski markgrof Dujam od Castella,

45 KOS, »Iz zgodovine...«, str. 114-129; KOSI, Spopad..., str. 91-94.

46 Listina je sačuvana samo kao insert u povelji iz 1418., koja se nalazi u Beču, Haus-, Hof- und Staatsarchiv, Allgemeine Urkundenreihe (dalje: AUR), listina 1418 I 27. Kritička će objava ove listine, koju pripremam s kolegom Robertom Kurelićem, biti objavljena u skoroj budućnosti.

47 KOSI, Spopad.., str. 91 . O ovim pojmovima vidi više u: Othmar HAGENEDER, »Die Länder im spätmittelalterlichen Verfassungsgefüge«, u: Lorenz MIKOLETZKY (ur.), Bericht über den 19. Österreichischen Historikertag in Graz 1992, Veröffentlichungen des Verbandes Österreichischer Historiker und Geschichtsvereine, sv. 28, Verband Österreichischer Geschichtsvereine, Beč - Graz, 1993., str. 11-25. Zahvaljujem kolegi Robertu Kureliću na ovoj referenci.

48 Beč, Haus-, Hof- und Staatsarchiv, AUR, listina 1374 III 16. Kritička će objava ove listine, koju pripremam s kolegom Robertom Kurelićem, biti objavljena u skoroj budućnosti.

49 Camillo DE FRANCESCHI, Storia documentata della Contea di Pisino, prir. Carlo DE FRANCESCHI, Società istriana di archeologia e storia patria,Venecija, 1964., dok. 8, str. 391-392. Isprava se tradicionalno datira 30. prosinca 1379., dok ju Miha Kosi datira 2. siječnja 1380.; usp. KOSI, Spopad..., str. 92. Datacija u ispravi glasi: »An vritag vor dem hailigen prehentag nach Krists geburt dreutzehenhundert jar darnach in dem archczigistem jare $\ll$.

50 Attilio HORTIS, »Documenti che riguardano la storia di Trieste e de'Walsee«, AT, ser. 2, sv. 4 (1876. 1877.), dok. 5, str. 70.

51 VERCI, Storia della Marca trivigiana..., sv. 16: appendix, dok. 1810.

52 Marialuisa BOTTAZZI, »Legislazione e politica nel Patriarcato di Aquileia del tardo medio evo: Note su una recente edizione degli Statuti di Monfalcone«, Quaderni Giuliani di Storia, sv. 27 (2006.), str. 
de iure gospodar Dvigrada uime akvilejske Crkve, bio u de facto neprijateljskim odnosima s moćnim glavarom Pazinske knežije, Hugonom VIII. od Devina.

$* * *$

Ovaj širi kontekst objašnjava dinamiku koja je dovela do sklapanja saveza između dvigradske komune i Hugona VIII. od Devina. Naime, Dvigrad se, kao sastavni posjed akvilejske Istarske markgrofovije, našao u posebno ranjivu položaju kada je građanski rat počeo harati Furlanijom, razdvojivši plemiće Patrijarhata u dva sukobljena tabora. Tu je ranjivost vješto iskoristio Hugon VIII. Devinski, bivši istarski markgrof i time poznato lice ondašnjim Dvegrajcima te kapetan susjedne Pazinske knežije koji je uživao znatno veći ugled i moć od Dujma od Castella. Ostaje otvorenim pitanjem koji su to točno događaji natjerali žitelje Dvigrada da se predaju pod »advokaturu i zaštitu gospodara Pazinske knežije«, kako sam tekst isprave svjedoči, nešto što je komuna običavala činiti i ranije. Komparativni materijal iz susjednih zemalja njemačkoga i talijanskog govornog područja u kasnom srednjem vijeku navodi na sljedeću interpretaciju: opasnost od koje je bila potrebna zaštita prouzročio je sam Hugon VIII. Devinski s jasnim ciljem jačanja vlastitih prerogativa i vlasti. ${ }^{53}$ Naime, mletački izvori svjedoče o (ponovno) rasplamsanim pograničnim sporovima između stanovnika akvilejskoga Oprtlja i podložnika Pazinske knežije, odnosno Hugona VIII. Devinskog. ${ }^{54}$ Vrlo je vjerojatno da su slični pogranični sporovi, koji su u zonama duž jurisdikcijskih granica mogli biti (re)aktivirani po potrebi, postojali i između Dvegrajaca i Pazinske knežije te da su upravo te differentiae iskorištene kao motiv za razne napade, od kojih je dvigradska komuna bila primorana tražiti primjerenu obranu. ${ }^{55} \mathrm{U}$ nemogućnosti pronalaska adekvatne obrane od svojih de iure gospodara, akvilejske Crkve paralizirane građanskim ratom i markgrofa Dujma od Castella zaokupljenoga u Furlaniji, Dvegrajci su se okrenuli najmoćnijem regionalnom vladaru, Habsburzima, i njihovu kapetanu - Hugonu VIII. od Devina. Riječima Andree Gamberinija, koji je sličnu dinamiku istraživao na području regije Emilia-Romagna u četrnaestom stoljeću, Hugon VIII. iskoristio je »klimu endemičnog nasilja, idealnog humusa za lokalne sile koje su svoju snagu crpile iz pružanja zaštite seljacima«. ${ }^{56}$ Proučavajući zavade frankonijskoga plemstva, Hillay Zmora zaklju-

379-381; BANIĆ, Venetian Istria..., str. 82.

53 Bilj. 9, 56 i 57 u ovom radu.

54 Venecija, ASV, Senato, Deliberazioni, Secreti alfabetici, reg. R (e), fol. 21r; Pietro KANDLER, Notizie storiche di Montona, Tipografia del Lloyd austro-ungarico, Trst, 1875., str. 175-177.

55 O tome da je takvih sukoba između Dvigrada i Pazinske knežije bilo i ranije svjedoči isprava patrijarha Markvarda iz 1368. godine, objavljena u: CDI, sv. 3, dok. 784, str. 1332. O naravi tih pograničnih sukoba vidi: Robert KURELIĆ, Daily Life on the Istrian Frontier: Living on a Borderland in the Sixteenth Century, Studies in the History of Daily Life (800-1600), sv. 7, Brepols, Turnhout, 2019., str. 133-195, posebice str. 144-160 i 178-190.

56 »Si determinò così un clima di endemica violenza, l'humus ideale per poteri locali che traevano la propria forza dall'azione di protezione dei rustici e che erano sempre pronti a giocare di sponda fra forze antagoniste.«; Andrea GAMBERINI, »La territorialità nel Basso Medioevo: Un problema chiuso? Osservazioni a margine della vicenda di Reggio«, u: Federica CENGARLE - Giorgio CHITTOLINI Gian Maria VARANINI (ur.), Poteri signorili e feudali nelle campagne dell'Italia settentrionale fra Tre e Quattrocento: Fondamenti di legittimità e forme di esercizio, Reti medievali E-book: Quaderni, sv. 4, Firenca, 2005., str. 47. 
čuje da su »plemići redovito uzrokovali opasnost i, uz cijenu, štitili od nje te se na taj način etablirali kao gospodari« - u suštini, Zmora ispravno primjećuje, radilo se o reketarstvu. ${ }^{57}$

Ovaj model širenja vlastitih ovlasti nije bio nepoznat u srednjovjekovnoj Istri i Devinski su ga, po svemu sudeći, imali priliku naučiti od svojih bivših seniora, grofova Goričkih. Naime, žitelji Bala 1333. godine opisali su Veneciji svoje daće i upravnu strukturu na sljedeći način:

»Također, ovi iz Bala davali su svake godine markgrofu gospodina patrijarha 400 libara malih denara. Njih je gospodin patrijarh dobivao radi toga da bi ih branio i zastupao protiv svakoga. Ipak, u prošlosti davali su zbog toga samo 200 libara malih denara, a koji put i manje. To nisu činili zbog obveze, bilo pisane ili kakve druge, već samo radi toga da ih brani, kao što je rečeno. Također, davali su grofu Gorice 100 modija pšenice, 50 raži i 50 mješina vina te jedan sir i jedno janje za svako stado ovaca toga mjesta. On je pak bio obvezan braniti ih i zastupati ih protiv svakoga. Nisu mu bili obvezani u rečenom iz drugog razloga, već samo da ih brani, kao što je rečeno za patrijarha. ( $^{58}$

Iz citiranoga je dokumenta jasno vidljiva slična razvojna dinamika: oslabljenu moć patrijarha prati pad legitimiteta (te samim time i pad daća koje mu je lokalno stanovništvo spremno platiti) dok moć susjednoga glavara Pazinske knežije raste.

Što se tiče samoga ureda advokature (orig. lat. advocatia), on se tradicionalno sastoji od prava prolijevanja krvi (ius sanguinis), odnosno administracije krivične pravde i ubiranja posebnih poreza (u slučaju Dvigrada to je novouspostavljena godišnja daća od dvanaest maraka, odnosno 96 libara malih denara) te obveze pružanja zaštite i zastupanja zajednice u sporovima.$^{59}$ Kako je u sklopu Markgrofovije Istre pravo prolijevanja krvi bilo povjereno isključivo istarskom markgrofu, u Dvigradu je sklapanjem ovoga saveza došlo do drastičnoga pada prerogativa glavnoga namjesnika akvilejskih patrijarha u Istri. Štoviše, iako isprava nigdje ne spominje neposlušnost akvilejskoj Crkvi ili potpuno podčinjavanje Habsburgovcima i Pazinskoj knežiji, fraza »trenutno našem jedinom gospodaru« (orig. lat. tunc domino nostro singularissimo), koja se odnosi na Hugona VIII. Devinskog, daje naslutiti da se dvigradska komuna željela u potpunosti podčiniti svojim novim advokatima.

$57 \gg$ Noblemen repeatedly produced the danger and, at a price, shielded against it, thereby establishing themselves as lords. The feud, in a very real sense, was a protection racket.«; Hillay ZMORA, State and Nobility in Early Modern Germany: The Knightly Feud in Franconia, 1440-1567 (dalje: ZMORA, State and Nobility), Cambridge University Press, Cambridge 1997., str. 108.

58 »Item predicti de Valle dabant marchioni domini patriarche libras quatuor centum parvorum quolibet anno, qui dominus patriarcha propterea tenebatur eos defendere et manutenere contra unamquam personam, quamvis elapsis temporibus dabant tantum dicta de causa libras CC parvorum et interdum minus, et hoc non faciebant tamquam obligati per scripturam vel aliter, sed solum ut deffenderentur, ut dictum est. Item dabant domino comiti Gorice modios $\mathrm{C}$ frumenti et $\mathrm{L}$ ordei et $\mathrm{L}$ congia vini et unum caseum et unum agnum pro quolibet troppo peccudum dicti loci. Et ipse tenebatur eos deffendere et manutenere contra quamlibet personam, nec sibi erant obligati in predictis nisi, ut supra dictum est de patriarcha, scilicet, ut deffenderentur.«; Vincenzo JOPPI, »Documenti goriziani del secolo XIV«, $A T$, ser. 2, sv. 14, br. 1 (1888.), dok. 104, str. 81-82. Prijevod, ponešto izmijenjen, preuzet je iz Lujo MARGETIĆ (prir.), Statut grada Bala, Adamić, Rijeka, 2007., str. 45.

59 BRUNNER, Land and Lordship..., str. 250-269; Zmora advokaturu naziva »the pith of lordship«; ZMORA, State and Nobility..., str. 107. 
Do takvoga potpunog podčinjavanja, međutim, ipak nije došlo. U oporuci Hugona VIII. iz 1390. godine Dvigrad ili bilo kakva prava nad ovom komunom nigdje se ne spominju ${ }^{60}$ Također, nijedan dosad poznat urbar Pazinske knežije ili računska knjiga austrijskih posjeda u Istri nigdje ne sadrže nikakav podatak o Dvigradu. ${ }^{61}$ Štoviše, Dvigrad je početkom 15. stoljeća ponovno pod vlašću akvilejskoga markgrofa Istre Kristofora od Cucagne i njegova namjesnika, Kopranina Lugnana Lugnanija, te stoga ponovno u sastavnom dijelu Markgrofovije Istre. ${ }^{62}$ Ovi podatci potvrđuju da je savez sklopljen 1386. godine bio kratkoga trajanja te da nije doveo do krajnjega cilja - potpunoga prelaska vlasništva nad Dvigradom s akvilejskih patrijarha na kuću Habsburg i njihove istaknute podanike, izdanke kuće Devin. Vrlo je vjerojatno da se Dvigrad vratio pod okrilje akvilejske Markgrofovije Istre početkom 1390-ih, u vrijeme patrijarha Ivana Soběslava i markgrofa Hordibora, nakon potpisivanja mirovnoga ugovora između Udina i Čedada i okončanja građanskoga rata u Furlaniji. Sve do konačnoga potpadanja pod vlast Mletačke Republike 1411. godine Dvigrad će ostati dijelom reliquiae reliquiarum Marchionatus Ystrię.

U svakom slučaju, dvigradska isprava iz 1386. godine svjedoči o proaktivnoj ulozi istarskih komuna, i to čak onih najskromnijih, poput dvigradske. Rječnikom Giuliana Milanija, akvilejske komune Istre bile su »latentne« - potpuno bi se aktivirale, preuzimajući na sebe veće ovlasti i autonomiju djelovanja na vanjskopolitičkom planu, samo u trenutcima krize i neizvjesnosti, periodima kada bi ih njihovi vladari iznevjerili. ${ }^{63}$ Baš kao što je to postulirao velik učenjak europskoga Trecenta, Marsilije od Padove, Dvegrajci su također smatrali da su dužni na poslušnost samo onim gospodarima koji će ih spremno oružanom silom braniti od neprijatelja. ${ }^{64}$ Dvigradska isprava tako otkriva novo, smjelo lice istarskih komuna podčinjenih Akvilejskom patrijarhatu, zajednica koje nikako nisu bile pasivni, »slabo organizirani« subjekti onemoćala crkvenoga gospodstva. ${ }^{65}$

60 Beč, Haus-, Hof- und Staatsarchiv, AUR, listina 1390 IX 11 (reprodukcija faksimila u KOSI, Spopad..., slika 25, str. 93).

61 Matjaž BIZJAK (prir.), Deželnoknežji obračuni za Kranjsko (Landesfürstliche abrechnungen für Krain), 1436-1448, Thesaurus memoriae: Fontes, sv. 12, Srednjeveške računske knjige za Slovenijo, sv. 1, Zgodovinski inštitut Milka Kosa ZRC SAZU, Ljubljana, 2016.

62 STEINWENTER, »Studien...«, str. 89-90.

63 Giuliano MILANI, I comuni italiani: Secoli XII-XIV, Laterza, Bari, 2005., str. 24-25.

64 Charles William PREVITÉ-ORTON (prir.), The Defensor Pacis of Marsilius of Padua, Cambridge University Press, Cambridge, 1928., str. 151-152. Vidi i: Serena FERENTE, »Popolo and Law: Late Medieval Sovereignty in Marsilius and the Jurists«, u: Richard BOURKE (ur.), Popular Sovereignty in Historical Perspective, Cambridge University Press, Cambridge, 2016., str. 96-114.

65 Usp. Fabio CUSIN, Il confine orientale d'Italia nella politica europea del XIV e XV secolo, 2. izd., Lint, Trst, 1977., str. 145. 


\section{DODATAK}

\section{KRITIČKO IZDANJE DVIGRADSKE LISTINE}

\section{Bilješke o transkripciji}

Tekst je transkribiran bez ikakvih intervencija u gramatičke oblike i s minimalnim intervencijama u pravopisne forme. Sve su kratice razriješene, ali brojke, u ovom tekstu isključivo rimske, nisu. Uvedena je suvremena punktuacija i regularizirana su velika i mala početna slova. Grafem »j《 uvijek je transkribiran kao »i«, isto kao i grafem »y《 ukoliko stoji za sufiksno »ii«; grafem »u« transkribiran je kao »V« ukoliko stoji za konsonant. Riječi koje je notar vidno razdvojio, a koje zajedno čine jedinstvenu riječ, spojene su (npr. advocatia umjesto izvorno napisano ad vocatia, devenimus umjesto izvorno napisano de venimus itd.). Urednikove emendacije stoje u uglatim zagradama. Srdačno zahvaljujem profesorici Nelli Lonza na savjetima i pomoći pri priređivanju ove isprave, kao i profesoru Mihi Kosiju koji mi je skrenuo pozornost na ovu ispravu i dao mi na korištenje svoju presliku ovoga dokumenta.

\section{Datum i mjesto:}

26. svibnja 1386. godine, Dvigrad.

\section{Regest}

Dvigradska komuna sklapa savez s Hugonom VIII. Devinskim i Leopoldom Habsburškim, upraviteljem i vladarom Pazinske knežije, imenujući ih advokatima Dvigrada i dodjeljujući im godišnji danak u iznosu od dvanaest maraka mletačkih solada radi osiguranja odgovarajuće zaštite i sigurnosti.

\section{Izvor}

Originalna listina u Beču, Institut für österreichische Geschichtsforshung, Urkundensammlung (A).

\section{Tekst listine}

Nos plebanus, vicarius, iudices, consilium, ac tota communitas Duorum Castrorum notum facimus ac pro nobis et nostris succesoribus tenore presentium publice profitemur quod, enim aliis temporibus retroactis nos et precesores nostri semper fuerimus sub advocatia et defensione dominationis Pisini Comitatus eidemque certas administrationes ex hoc impendirimus ${ }^{66}$, sic - propter maiorem nostri castri predicti ac bonorum nostrorum defensionem et protectionem - cum magnifico et potenti domino domino Hugone de Duino comite, capitaneo Carniole, tunc domino nostro singularissimo loco et vice ilustrissimi domini Leupoldi, yncliti ducis Austrie et cetera, domini nostri graciosi, sponte ad talem devenimus unionem, videlicet quod amodo in antea sub dicti domini ducis Austrie et suorum heredum et succesorum advocatia, defensione et gubernatione esse intendimus, et volumus eidemque seu eius vice gerenti Pisini anuatim in festo Sancti Martini duodecim

66 Sic: pro imenderimus. 
marcas solidorum Venetorum ministrando ac sine dilatione porigendo, promitentes insuper fide nostra mediante contra dictum dominum nostrum ducem seu eius castra aut subditos nulo modo processuros, ymo potius eidem ac eius vice gerenti in Pisino tamquam vero advocato nostro in omnibus fore obedientes, omni fraude et dubio procul moto.

In cuius rey testimonium has patentes nostras literas dedimus nostri Comuni sigilo apensione munitas.

Datum in Duobus Castris sub anno MOCCCO octuagesimo VIO, indictione nona, die XXVIO mensis madii.

[S.N] Ego Iohanes quondam ser Petri imperiali auctoritate notarius nunc [notarius] Duorum Castrorum hiis omnibus interfui et rogatus scribere, scripsi et signum meum robur aposui.

\section{Preslika listine}

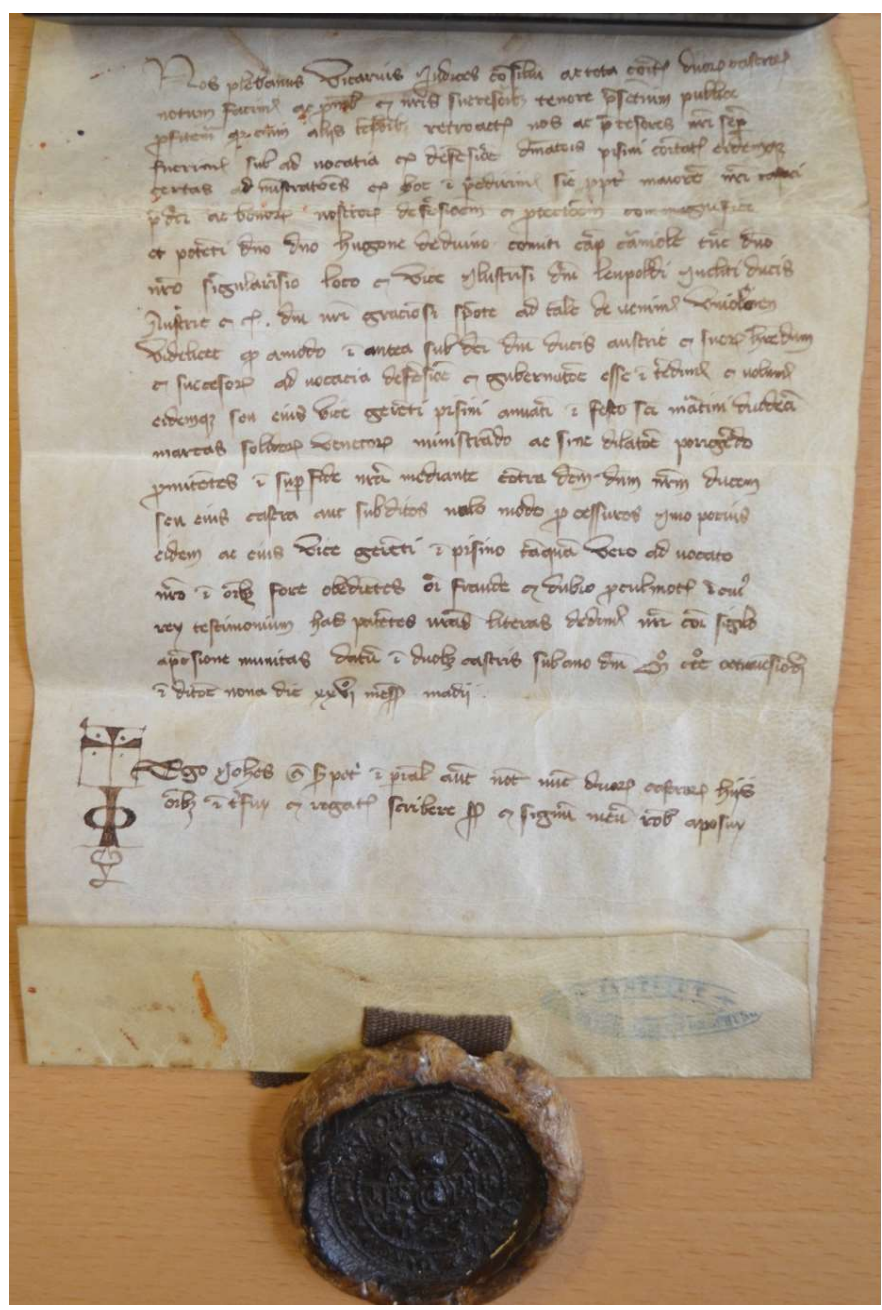




\section{Prijevod listine}

Mi, župnik, vikar, sudci, vijeće i cijela zajednica Dvigrada obznanjujemo te uime nas i naših nasljednika ovom ispravom javno objavljujemo sljedeće:

budući da smo u prošlosti mi i naši prethodnici radi zaštite uvijek bili pod advokaturom vlasti Pazinske knežije i njoj smo na račun toga predali određene uprave, na isti način radi bolje protekcije i zaštite našega prethodno spomenuta kaštela te naših dobara - svojevoljno ulazimo u savez s veličanstvenim i moćnim gospodinom, gospodinom Hugonom Devinskim, grofom, kapetanom Kranjske te trenutno našim jedinim gospodarom uime našega velemožnog gospodina Leopolda, časnoga vojvode Austrije i tako dalje. Naime, odsad pa nadalje namjeravamo da advokatura, obrana i uprava budu u rukama rečenoga vojvode Austrije te njegovih potomaka i nasljednika i želimo njemu istome ili njegovu namjesniku u Pazinu dodijeliti dvanaest maraka mletačkih solada svake godine na svetkovinu sv. Martina, i to bez ikakvih odgađanja ponuđenoga. Usto, vjerno obećavamo da ni u kojem načinu nećemo nastupati protiv navedenoga našeg gospodina vojvode ili njegovih utvrda ili podložnika, već naprotiv, da ćemo njemu istomu, kao i njegovu namjesniku u Pazinu, kao našemu pravomu advokatu, u svemu biti potpuno poslušni, bez ikakvih obmana i dvojbi.

U svjedočanstvo ovoga čina izdali smo ovu našu službenu ispravu osnaženu visećim pečatom naše komune.

Dano u Dvigradu, godine tisuću tristo osamdeset šeste, devete indikcije, dana dvadeset šestoga mjeseca svibnja.

[N.Z.] Ja, Ivan, sin pokojnoga Petra, carskom ovlašću notar, trenutno [notar] Dvigrada, upitan i zamoljen da sve ovo zapišem, zapisao sam i potvrdio dodatkom svoga znaka. 


\section{SAŽETAK}

\section{Dominium quoad protectionem: Savez Dvigrada s Hugonom VIII. Devinskim iz 1386. godine}

Autor priređuje i analizira neobjavljenu listinu, izdanu 1386. godine u Dvigradu, kojom je sklopljen savez između dvigradske komune, nominalno pod jurisdikcijom akvilejskih patrijarha, i Hugona VIII. Devinskog, kapetana susjedne Istarske grofovije, upravne regije pod vrhovnom vlašću kuće Habsburg. Ističući razne nedaće koje su pogodile Akvilejski patrijarhat i Markgrofoviju Istru tijekom zadnjih desetljeća 14. stoljeća, imenovanje je Hugona VIII. kao novoga advokata (tj. zaštitnika, lat. advocatus) Dvigrada interpretirano u svjetlu jurisdikcijskoga pluraliteta, poroznih granica istarskoga srednjovjekovlja $i$, najvažnije, recipročne naravi odnosa između gospodara i podanika. Autor zaključuje da je novoutemeljeni savez bio prvenstveno motiviran nemoći tadašnjih istarskih markgrofova da svojim podanicima pruže primjerenu vojnu zaštitu, pogotovo u kontekstu tradicionalnih graničnih sporova između podanika akvilejske Crkve s jedne i Istarske grofovije s druge strane. Štoviše, kako je Akvilejski patrijarhat potonuo u građanski rat, koji je suprotstavio promletački tabor na čelu s Udinama protiv propadovanskoga, koji su vodili de iure patrijarh Filip d'Alençon i Čedad, Hugon VIII. Devinski postao je jedan od najmoćnijih regionalnih vlastodržaca. Istovremeno, tadašnji istarski markgrof, Dujam od Castella, otvoreno je podržavao promletački front te mu je stoga zakoniti patrijarh d'Alençon osporavao legitimitet ureda; Hugon VIII., s druge strane, ostao je službeno neutralan u ovom sukobu, ali je prešutno podržavao propadovanski savez, postajući de facto neprijatelj istarskoga markgrofa Dujma, de iure gospodara Dvigrada. Upravo je u tom kontekstu neprijateljstva, krize i neizvjesnosti građanskoga rata dvigradska komuna, na čije su teritorije najvjerojatnije pljačkaški upadali podanici Pazinske knežije uz podršku samoga Hugona VIII., odlučila sklopiti savez sa svojim moćnim susjedom, preferirajući imenovati tadašnjega kapetana Pazina kao svojega službenog zaštitnika i plaćati mu godišnji danak (tj. reket), nego ostati vjerna nemoćnoj akvilejskoj Crkvi. 


\section{SUMMARY}

\section{Dominium quoad protectionem: The Alliance between Dvigrad and Hugo VIII of Duino from 1386}

The author edits and analyzes an inedited charter, issued in Dvigrad in 1386, by which an alliance was forged between the Commune of Dvigrad, nominally under the jurisdiction of Aquileian patriarchs, and Hugo VIII of Duino, the captain of the neighboring County of Istria, a jurisdictional region under the supreme authority of House Habsburg. Highlighting various calamities that plagued the Patriarchate of Aquileia and the Margraviate of Istria during the final decades of the 14th century, the appointment of Hugo VIII as the new guard (Lat. advocatus) of Dvigrad is interpreted in the light of jurisdictional plurality, porous boundaries of Istrian Middle Ages, and, most importantly, the reciprocal nature of the lord-subject relationship. The author concludes that the newly forged alliance was primarily motivated by the inability of the incumbent Istrian margraves to offer adequate military protection to their subjects, especially in the context of traditional border disputes between the subjects of the Church of Aquileia and the subjects of the County of Istria. Moreover, as the Church of Aquileia plunged into civil war which pitted the pro-Venetian faction led by Udine against the pro-Paduan faction led by the de iure patriarch, Philip d'Alençon and Cividale, Hugo VIII of Duino emerged as one of the most powerful regional potentates. At the same time, the incumbent margrave of Istria, Domnius of Castello, openly supported the pro-Venetian front and as such the legitimacy of his office was disputed by the lawful patriarch Alençon; Hugo VIII, on the other hand, remained officially neutral in the conflict, but he tacitly supported the pro-Paduan alliance, becoming a de facto enemy of Margrave Domnius, the de iure lord of Dvigrad. It was in this context of enmity, crisis, and the uncertainty of civil war that the Commune of Dvigrad, most probably pillaged by the neighboring subjects of the County of Pazin backed by Hugo VIII, decided to forge an alliance with their more powerful neighbor, preferring to constitute the incumbent captain of Pazin as their official guard and to pay him a new annual tax (i.e. a protection racket) than to remain faithful to the powerless Church of Aquileia. 


\section{RIASSUNTO}

\section{Dominium quoad protectionem: Alleanza di Duecastelli con Ugo VIII di Duino del 1386}

L'autore dispone e analizza un documento inedito, rilasciato nel 1386 a Duecastelli, con il quale fu stabilita l'alleanza tra il comune di Duecastelli, nominalmente sotto la giurisdizione dei Patriarchi di Aquileia, e Ugo VIII di Duino, capitano del vicino Marchesato d'Istria, regione amministrativa sotto l'autorità suprema della casa d'Asburgo. Sottolineando vari disagi che colpirono il patriarcato di Aquileia e il Margraviato d'Istria negli ultimi decenni del XIV secolo, la nomina di Ugo VIII a nuovo avvocato (ovvero protettore, lat. advocatus) di Duecastelli fu interpretata alla luce della pluralità delle giurisdizioni, dei confini porosi del medioevo istriano e, la più importante reciprocità del rapporto tra autorità e sudditi. L'autore conclude che la nuova alleanza stabilita fu motivata soprattutto dall'incapacità dei margravi istriani di allora nell'offrire una protezione militare adeguata ai propri sudditi, soprattutto nel contesto delle tradizionali controversie frontaliere tra $\mathrm{i}$ sudditi della Chiesa d'Aquileia da una parte e il Marchesato d'Istria dall'altra parte. Inoltre, dato che il patriarcato di Aquileia sprofondò nella guerra civile che vide opporsi la parte pro veneziana, con a capo Udine, contro quella pro padovana guidata de iure dal patriarca Filippo d'Alençon e Cividale del Friuli, Ugo VIII di Duino diventò uno dei più potenti sovrani regionali. Contemporaneamente, il margravio istriano di allora, Doimo di Castello, sosteneva apertamente il fronte pro veneziano e per quel motivo, il patriarca legittimo d'Alençon, contestava la legittimità dell'ufficio; Ugo VIII, dall'altra parte rimase ufficialmente neutrale in quel conflitto, però sostenne tacitamente l'alleanza pro padovana, diventando de facto nemico del margravio istriano Doimo, de iure padrone di Duecastelli. Proprio in quel contesto di ostilità, crisi e incertezza della guerra civile il comune di Duecastelli, su cui territorio presumibilmente le invasioni dei rapinatori erano effettuate dai sudditi della Contea di Pisino con il sostegno di Ugo VIII stesso, decise di stipulare l'alleanza con il proprio vicino potente, preferendo nominare il capitano di Pisino di allora a proprio protettore ufficiale e a pagargli il tributo annuale (ovvero il racket) che rimanere fedele all'impotente Chiesa di Aquileia. 